\title{
EFFECTS OF PACKAGING AND TEMPERATURE ON POSTHARVEST OF ATEMOYA
}

\author{
FABIO YAMASHITA ${ }^{2}$, LUCIA HELENA DA SILVA MIGLIORANZA ${ }^{2}$, LILIAN DE AZEVEDO MIRANDA ${ }^{3}$, \\ CHRISTIAN MARLON DE ALMEIDA E SOUZA ${ }^{4}$
}

\begin{abstract}
Effects of refrigerated storage and different packages on postharvest behaviour of fruits of atemoya (Annona cherimola x A. squa$m o s a) \mathrm{cv}$. PR3 were investigated. Fruits were individually sealed in copolymer (PD-955) and low-density polyethylene (LDPE) bags and stored for 21 days at $15^{\circ} \mathrm{C}$ or $25^{\circ} \mathrm{C}$. Then they were unwrapped and maintained at $25^{\circ} \mathrm{C}$, for ripening. Weight loss and firmness of fruits were both affected by storage time, temperature and packaging. Weight loss in packaged atemoyas was lower than in the control, non-wrapped fruits. A non-trained panel scored the atemoyas for overall eating quality and appearance. Fruits sealed in LDPE did not ripen, probably due to an injurious atmosphere developed inside the package. Atemoyas packaged in PD-955 film had a shelf-life of 17 days against 13 days of the control ones, both stored at $15^{\circ} \mathrm{C}$, an increase of $30 \%$ on shelf-life.
\end{abstract}

Index terms: Annona cherimola x A.squamosa; modified atmosphere; refrigerated storage.

\section{EFEITO DO TIPO DE EMBALAGEM E DA TEMPERATURA NA CONSERVAÇÃO DE ATEMÓIAS ${ }^{1}$}

RESUMO - Testou-se o comportamento da atemóia (Annona cherimola x A. squamosa) cv. PR3 frente a armazenagem refrigerada e a utilização de diferentes embalagens. Os frutos foram embalados individualmente em sacos de polietileno de baixa densidade (PEBD) ou em sacos feitos de um copolímero (PD-955), e armazenados por 21 dias, a $15^{\circ} \mathrm{C}$ ou $25^{\circ} \mathrm{C}$, quando foram então desembalados e mantidos a $25^{\circ} \mathrm{C}$ para amadurecerem. Tanto a perda de massa como a firmeza dos frutos foram afetadas pela embalagem, tempo e temperatura de armazenagem. A perda de massa pelas atemóias embaladas foi significativamente menor do que naquelas sem embalagem, que serviram de controle. Provadores não treinados ordenaram as atemóias em função do sabor e aparência. Frutos embalados com PEBD não amadureceram, provavelmente devido ao desenvolvimento de uma atmosfera tóxica ao fruto no interior da embalagem. As atemóias embaladas com PD-955 apresentaram vida de prateleira de 17 dias contra 13 dias dos frutos-controle, ambos a $15^{\circ} \mathrm{C}$, que representam um aumento de $30 \%$ na vida de prateleira.

Termos para indexação: Annona cherimola x A. squamosa; atmosfera modificada; refrigeração.

\section{INTRODUCTION}

Atemoya is an hybrid of Annona cherimola (Mill.) with A. squamosa (L.). It is a semi-deciduous, exotic subtropical fruit, consumed in many countries throughout the world (Manica, 1994). Rapid skin browning and softening are the major problems that affect the marketing of atemoyas. Their shelf-life extension is important for commercial purposes and information about fruit behaviour under modified atmosphere is relatively scarce.

Refrigeration associated with modified atmosphere packing (MAP) is used for extending shelf-life of vegetables and fruits. A temperature from $8^{\circ} \mathrm{C}$ to $15^{\circ} \mathrm{C}$, according to cultivar, is considered optimum for atemoya storage (Batten, 1990). Lower temperatures can cause chilling injury (blackening of skin and browning of flesh) and other physiological disorders (Brown et al, 1988; Batten, 1990; Manica, 1994).

MAP usually involves the use of flexible plastic films, with specific permeability to different gases and/or water vapour. Wrapped product, through respiration and transpiration processes, modifies the atmosphere, altering its metabolism. Such a change may extend its shelflife (Ben-Yehoshua et al,1983; Ben-Yehoshua, 1985) or induce physiological disorders, if the film permeability was inadequate (Zagory \& Kader, 1988).

The present test determined the effect of two temperatures and two different modified atmosphere packages on the firmness, weight loss and overall acceptance of atemoyas and their consequent shelf life.

\section{MATERIALANDMETHODS}

\section{Preparation of fruits}

One hundred and fifty atemoyas fruits, cv PR3, were manually harvested at physiological maturity (pre-climacteric hard green stage) from commercial orchards at São Sebastião da Amoreira, Parana State, Brazil, located at $23^{\circ} 22^{\prime} \mathrm{S}$ latitude, $51^{\circ} 10^{\prime} \mathrm{W}$ longitude and altitude of 585 meters. They were sorted for weight $(391.5 \pm 56.6 \mathrm{~g})$ and physiological damage. Fifty fruits were individually sealed in film made with the co- polymer Cryovac ${ }^{\circledR}$ PD-955 (Grace Products) $(150 \mathrm{~mm}$ x $150 \mathrm{~mm})$ and other fifty fruits in a low-density polyethylene film (LDPE) $(150 \mathrm{~mm} \times 150 \mathrm{~mm}$ ), using a manual sealer. Fifty fruits unwrapped served as control. The packaging treatments were divided into two groups and placed in storage chambers at $15 \pm 1^{\circ} \mathrm{C}(85-95 \% \mathrm{RH})$ or $25 \pm 1^{\circ} \mathrm{C}(80-90 \% \mathrm{RH})$. Films characteristics are shown in Table 1.

TABLE 1 - Physical characteristics of films used as atemoya package

\begin{tabular}{|c|c|c|}
\hline Physical characteristics & PD-955 ${ }^{1}$ & LDPE $^{2}$ \\
\hline Density $\left(\mathrm{g} \mathrm{m}^{-3}\right)$ & 0.92 & 0.92 \\
\hline Thickness ( $\mathrm{m}$ ) & 15.0 & 24.5 \\
\hline Water transmission rate * $\left(\mathrm{g} \cdot \mathrm{m}^{-2} \cdot 24 \mathrm{~h}^{-1}\right)$ & 22.90 & 19.95 \\
\hline $\mathrm{O}_{2}$ transmission rate ${ }^{* *} \quad\left(\mathrm{~cm}^{3} \cdot \mathrm{m}^{-2} \cdot 24 \mathrm{~h}^{-1}\right)$ & 9,870 & 7,081 \\
\hline $\mathrm{CO}_{2}$ transmission rate ${ }^{* * *}\left(\mathrm{~cm}^{3} \cdot \mathrm{m}^{-2} \cdot 24 \mathrm{~h}^{-1}\right)$ & 39,021 & 23,749 \\
\hline
\end{tabular}

$* 28^{\circ} \mathrm{C}-90 \% \mathrm{RH} ; * * 25^{\circ} \mathrm{C}-0 \% \mathrm{RH}-1$ atm partial pressure of $\mathrm{O}_{2} ; * * 25^{\circ} \mathrm{C}$ - 0\% RH - 1 atm partial pressure of $\mathrm{CO}_{2} ; 1$ - Copolymer CryovacÒ D-955; 2 Low density polyethylene

\section{Sampling}

At intervals of 2 or 4 days, 5 samples were taken out of storage, from each treatment, at random. Two fruits were evaluated for weight loss, total soluble solids (TSS), titratable acidity (TA), reported as citric acid (AOAC, 1990) and firmness (Table 2). The other three fruits were unwrapped and placed in a storage chamber at $25 \pm 1^{\circ} \mathrm{C}$, until they reached the soft-ripe stage, when they were evaluated (Table 3 ).

Firmness was determined using a Texture Analyzer TA-TX2i (Stable Microsystems, Hoslemere, Surrey, United Kingdom). The instrument was fitted with a TA-25 probe (cylinder with $6.0 \mathrm{~mm}$ diam.), programmed to penetrate $10 \mathrm{~mm}$. Each fruit was compressed longitudinally at a constant crosshead speed of $50 \mathrm{~mm} \mathrm{sec}^{-1}$, on five different points. The highest rupture force $(\mathrm{N})$ for each point was used to calculate the average firmness for each fruit.

1 (Trabalho 161/2001). Recebido: 08/10/2001. Aceito para publicação: 06/09/2002.

2 Professores, Depto. Tecnologia de Alimentos e Medicamentos, Universidade Estadual de Londrina, C.P. 6001, CEP: 86051-970, Londrina, PR. E-mail: fabioy @ uel.br. Tel: (43) 371-4565 ramal 207

3 Pós Graduanda do Depto. de Tecnologia de Alimentos e Medicamentos, UEL, Londrina, PR.

4 Aluno Iniciação Científica, Depto. Tecnologia de Alimentos e Medicamentos, UEL, Londrina, PR. 
When the atemoyas reached the ripe stage, they were submitted to informal sensory evaluation that included skin color, spots, mould incidence and flavour.

\section{Data analyses}

The data were analysed (means, standard deviations and linear regressions) using Statistical Analysis Systems (SAS $\left.{ }^{\circledR}, 1985\right)$.

\section{RESULTS AND DISCUSSION}

\section{Effects of packaging}

Control fruits and fruits wrapped with PD-955 film ripened after 0 to 5 days, depending on the temperature and storage time (Table 3). At this stage, fruit for consumption should be light green in color; have no physiological injury or decay and their flavour and texture should be characteristic of ripe fruits.

After 17 days, at $15^{\circ} \mathrm{C}$, fruits wrapped in PD-955 ripened within one day at $25^{\circ} \mathrm{C}$ after unwrapping. These atemoyas were lightly spotted, no decay was detected, and flavour and texture were characteristic of ripe fruit. Control fruits were spotted and excessively soft.

After 21 days at $15^{\circ} \mathrm{C}$, all fruits were commercially unacceptable, due to spotted skin, decay, excessive softening and off-flavour. After three days at $25^{\circ} \mathrm{C}$, fruits wrapped in PD- 955 film ripened normally one day after unwrapping. But after 9 days at $25^{\circ} \mathrm{C}$, the wrapped fruits developed an abnormal odour, and showed black or brown skin, developed decay and did not soften normally. Control fruit were excessively soft and senescent.

Atemoyas sealed with LDPE did not ripen and it developed an off-flavour, probably due to an injurious atmosphere inside the package, which must have affected its normal metabolism. This atmosphere should have been created by the relatively high respiration rates of the fruits, compared to the low oxygen and carbon dioxide permeability of the film (Zagory \& Kader, 1988).

Titratable acidity of fruits wrapped with LDPE and stored at 15 and $25^{\circ} \mathrm{C}$ varied from 0.07 to $0.12 \%$ citric acid (Table 2). Soluble solids increased up to 9 days, at $25^{\circ} \mathrm{C}$ and up to 14 days, at $15^{\circ} \mathrm{C}$, then a strong decreased, to less than initial values after 11 and 22 days storage, at $25^{\circ} \mathrm{C}$ or $15^{\circ} \mathrm{C}$, respectively.

TABLE 2 - Effect of storage time at $15^{\circ} \mathrm{C}$ or $25^{\circ} \mathrm{C}$ on the titratable acidity, total soluble solids and weight loss in wrapped and nonwrapped atemoyas

\begin{tabular}{|c|c|c|c|c|c|c|}
\hline \multirow{3}{*}{$\begin{array}{c}\text { Film } \\
\text { wrap }\end{array}$} & \multirow{3}{*}{$\begin{array}{c}\text { Temp } \\
\left({ }^{\circ} \mathrm{C}\right)\end{array}$} & \multirow{3}{*}{$\begin{array}{c}\begin{array}{c}\text { Storage } \\
\text { time (days) }\end{array} \\
0\end{array}$} & \multirow{2}{*}{\multicolumn{2}{|c|}{$\begin{array}{c}\text { Titratable } \\
\text { acidity (\%) }\end{array}$}} & \multirow{2}{*}{$\begin{array}{l}\text { Total soluble } \\
\text { solids ( }{ }^{\circ} \text { Brix) }\end{array}$} & linear regression for weight loss \\
\hline & & & & & & $y\left(\mathrm{~g} \mathrm{~kg}^{-1}\right)$ \\
\hline & & & 0.09 & 0.01 & 10.50 .9 & $y=-183.0+92.5 x$ \\
\hline & & 6 & 0.10 & 0.01 & 22.20 .8 & $R^{2}=0.81 \quad P<0.001$ \\
\hline & & 10 & 0.13 & 0.01 & 22.60 .6 & $\mathrm{sd}=330.2 \quad \mathrm{n}=11$ \\
\hline & & 14 & 0.16 & 0.06 & 20.82 .5 & \\
\hline & & 18 & 0.13 & 0.03 & 23.40 .2 & \\
\hline & & 22 & 0.17 & 0.03 & 23.62 .9 & \\
\hline \multirow[t]{5}{*}{ PD-955 } & 15 & 6 & 0.08 & 0.01 & 22.01 .1 & $y=-49.7+9.8 x$ \\
\hline & & 10 & 0.07 & 0.01 & 25.21 .7 & $R^{2}=0.62 \quad P<0.004$ \\
\hline & & 14 & 0.10 & 0.02 & 22.60 .6 & $\mathrm{sd}=57.0 \quad \mathrm{n}=11$ \\
\hline & & 18 & 0.10 & 0.04 & 21.05 .6 & \\
\hline & & 22 & 0.09 & 0.03 & 17.94 .4 & \\
\hline \multirow[t]{5}{*}{ LDPE } & 15 & 6 & 0.07 & 0.01 & 20.33 .9 & $y=-4.1+5.5 x$ \\
\hline & & 10 & 0.09 & 0.04 & 20.53 .5 & $R^{2}=0.56 \quad P<0.008$ \\
\hline & & 14 & 0.12 & 0.01 & 22.40 .5 & $\mathrm{sd}=36.0 \quad \mathrm{n}=11$ \\
\hline & & 18 & 0.07 & 0.03 & 12.42 .3 & \\
\hline & & 22 & 0.09 & 0.03 & 15.51 .3 & \\
\hline \multirow[t]{4}{*}{ control } & 25 & 0 & 0.09 & 0.01 & 16.50 .9 & $y=-29.2+173.2 x$ \\
\hline & & 4 & 0.12 & 0.03 & 22.50 .7 & $R^{2}=0.97 \quad P<0.001$ \\
\hline & & 9 & 0.12 & 0.01 & 20.42 .2 & $\mathrm{sd}=142.9 \quad \mathrm{n}=7$ \\
\hline & & 11 & 0.13 & 0.01 & 20.21 .5 & \\
\hline \multirow[t]{3}{*}{ PD-955 } & 25 & 4 & 0.06 & 0.02 & $\begin{array}{lll}19.5 & 0.3\end{array}$ & $y=-14.3+14.2 x$ \\
\hline & & 9 & 0.09 & 0.01 & 18.02 .8 & $R^{2}=0.53 \quad P<0.063$ \\
\hline & & 11 & 0.05 & 0.01 & 15.74 .5 & $\mathrm{sd}=61.8 \quad \mathrm{n}=7$ \\
\hline \multirow[t]{3}{*}{ LDPE } & 25 & 4 & 0.07 & 0.01 & 17.54 .9 & $y=0.58+22.7 x$ \\
\hline & & 9 & 0.07 & 0.01 & 20.90 .5 & $R^{2}=0.74 \quad P<0.013$ \\
\hline & & 11 & 0.09 & 0.01 & 12.23 .5 & $\mathrm{sd}=62.1 \quad \mathrm{n}=7$ \\
\hline
\end{tabular}

TABLE 3 - Effect of storage time at $15^{\circ} \mathrm{C}$ or $25^{\circ} \mathrm{C}$ on the titratable acidity, total soluble solids and weight loss in wrapped and nonwrapped atemoyas ripped at $25^{\circ} \mathrm{C}$

\begin{tabular}{|c|c|c|c|c|c|c|}
\hline $\begin{array}{l}\text { Film } \\
\text { wrap }\end{array}$ & $\begin{array}{l}\text { Temp } \\
\left({ }^{\circ} \mathrm{C}\right)\end{array}$ & $\begin{array}{c}\text { Storage } \\
\text { time (days) }\end{array}$ & $\begin{array}{l}\text { Days to } \\
\text { ripening }\end{array}$ & $\begin{array}{l}\text { Total soluble } \\
\text { solids ('Brix) }\end{array}$ & $\begin{array}{c}\text { Titratable } \\
\text { acidity (\%) }\end{array}$ & $\begin{array}{c}\text { Firmness } \\
(\mathrm{N})\end{array}$ \\
\hline \multirow[t]{3}{*}{ control } & 15 & 5 & $2-3$ & 20.90 .8 & $0.08 \quad 0.03$ & 4.51 .3 \\
\hline & & 9 & $1-2$ & $26.0 \quad 1.2$ & 0.110 .02 & $2.4 \quad 1.3$ \\
\hline & & 13 & $0-1$ & 23.32 .7 & 0.140 .01 & 2.60 .6 \\
\hline \multirow[t]{4}{*}{ PD-955 } & 15 & 5 & $3-4$ & 18.41 .2 & $0.08 \quad 0.01$ & 7.43 .6 \\
\hline & & 9 & $0-3$ & 20.81 .9 & $0.08 \quad 0.01$ & $\begin{array}{ll}3.8 & 1.0\end{array}$ \\
\hline & & 13 & $0-2$ & 20.01 .5 & 0.100 .01 & 16.96 .8 \\
\hline & & 17 & $0-1$ & 22.20 .5 & 0.100 .08 & 8.32 .2 \\
\hline \multirow[t]{2}{*}{ control } & 25 & 0 & $4-5$ & 20.71 .8 & 0.120 .01 & 4.71 .4 \\
\hline & & 3 & 1 & 21.71 .3 & 0.140 .07 & $\begin{array}{ll}5.7 & 2.2\end{array}$ \\
\hline PD-955 & 25 & 3 & 1 & 25.91 .0 & $0.10 \quad 0.04$ & 3.40 .5 \\
\hline
\end{tabular}

According to Ben-Yehoshua (1985), the main function of individual packaging is to reduce respiration rate and water loss by transpiration, and by maintaining an appropriate water-saturated atmosphere, and a gaseous concentration to avoid an injurious atmosphere inside the package, which could affect the fruits normal metabolism.

\section{Weight loss}

One of the major factors responsible for the short shelf life of control atemoyas was the high weight loss that caused shrivelling and loss of brightness. Weight loss of both, packaged and non-packaged fruits increased with time of storage and was significantly reduced (P£0.05) by film wrapping (Table 2). Weight loss rate of packaged atemoyas was about 10 times lower than control, and after 22 days at $15^{\circ} \mathrm{C}$ and 11 days at $25^{\circ} \mathrm{C}$ non-sealed fruits lost $20 \%$ of their original weight and became unattractive because of their wrinkly appearance. Packaged atemoyas lost only $0.8-2.9 \%$ at the same time and temperatures. Humidification of the storage chamber could probably extend the shelf-life of the non-packaged product, but operational and fixed costs, as well as decay caused by molds, would increase.

\section{Total soluble solids}

Total soluble solids of wrapped and non-wrapped atemoyas increased during the initial 10-14 days of storage (Table 2), but decreased after 15 days at $15^{\circ} \mathrm{C}$ or 10 days at $25^{\circ} \mathrm{C}$ in wrapped fruits, particularly these in LDPE film. The low permeability of the LDPE film to oxygen and carbonic dioxide probably created an injurious atmosphere inside de package and altered metabolism of the fruit. Control fruits had the highest level of soluble solids, whereas the fruits wrapped with LDPE had the lowest level. This could be due to accelerated ripening in non-wrapped atemoyas because of their higher respiration rates. There was also a concentration effect due to higher water loss in control fruits.

\section{Titratable acidity}

Titratable acidity of control fruits increased $(0.09 \pm 0.01$ to 0.13 $\pm 0.01 \%$ citric acid) up to the ninth day of storage and then stabilised (Table 2). The acidity of the majority of the fruits decreases during ripening and storage time but for atemoyas this increase is characteristic although was less than expected, since Manica (1994) observed a variation of titratable acidity from 0.19 to $0.26 \%$ citric acid for mature atemoya fruits. This difference probably is due to cultivar, weather conditions and cultural practices. The packed atemoyas showed almost constant acidity values $(0.05 \pm 0.01$ to $0.10 \pm 0.04 \%$ citric acid $)$ at $15^{\circ} \mathrm{C}$ and at $25^{\circ}$ $\mathrm{C}$ during storage.

\section{Firmness}

Initial firmness of fruits was $4.7 \pm 1.4 \mathrm{~N}$, but it changed during 
storage, according to temperature and type of film package (Table 3). PD-955 packaged atemoyas, stored at $15^{\circ} \mathrm{C}$, maintained the firmness higher than the initial value and varied from 7.4 to $16.9 \mathrm{~N}$, except after 9 days, when the firmness dropped to $3.8 \mathrm{~N}$ and the respective controls showed a decrease on their firmness, characteristic of the ripening. The packaging retarded the ripening and consequently maintained the physical structure of the fruit skin. Nevertheless, those stored at $25^{\circ} \mathrm{C}$ for three days presented a little variation on firmness (3.4 to $5.7 \mathrm{~N}$ ).

\section{CONCLUSION}

The presence and the type of film package, as well as storage temperature, affected the shelf life of atemoya fruits. Their overall appearance and firmness determined the end of shelf life for control atemoyas.

Individual film sealing of atemoya cv. PR3 extended their shelf life. At $15^{\circ} \mathrm{C}$, non-wrapped atemoyas had a shelf life of 13 days against 17 days of those wrapped with PD-955. LDPE film showed to be inadequate to package atemoya because of its low permeability to oxygen and dioxide carbon. The fruits should be unwrapped before ripening at room temperature to avoid off-flavour development because at this temperature the respiration rates are higher and due to relatively low film permeability could be created an injurious atmosphere to the fruit inside the package.

\section{REFERENCES}

AOAC. Official methods of analysis. Washington D C: Association of Official Analytical Chemists, 1990.

BATTEN, D.J. Effect of temperature on ripening and postharvest life of fruit of atemoya (Annona cherimolia Mill. x A. squamosa L.) cv. African Pride. Scientia Horticulturae, Amsterdan, v.45, p.129-136, 1990.

BEN-YEHOSHUA, S. Individual seal-packaging of fruit and vegetables in plastic film - a new postharvest technique. HortScience, Alexandria, v.20, p.32-37, 1985.

BEN-YEHOSHUA, S.; SHAPIRO, B.; CHEN, Z.E.; LURIE, S. Mode of action of plastic film in extending life of lemon and bell pepper fruits by alleviation of water stress. Plant Physiology, Bethesda, v.73, p.8793, 1983.

BROWN, B.I.; WONG, L.S.; NISSEN, R.J. Comparative studies on the postharvest physiology of fruit from different species of Annona (custard apple). Journal of Horticultural Science, Ashford, v.63, p.521-528, 1988 .

MANICA, I. Fruticultura. Cultivo das Anonáceas Ata, Cherimólia, Graviola. Porto Alegre: Evangraf, 1994.

SAS ${ }^{\circledR}$. SAS User’s Guide: Statistics. Cary: SAS Institute Inc., 1985.

ZAGORY, D.; KADER, A.A. Modified atmosphere packaging of fresh produce. Food Technology, Chicago, v.42, p.70-74, 76-77, 1988. 